\title{
HYPOPHYSECTOMY FOR SEVERE SPINAL CORD COMPLICATIONS FROM BREAST CARCINOMA
}

\author{
By R. P. Sengupta and L. P. Lassman \\ Nerwcastle University Hospitals, Regional Neurological Centre, \\ Newcastle General Hospital, Newcastle upon Tyne
}

IT is over 75 years since Beatson (1896) first advocated endocrine ablation for cancer of the breast. Since then the role of different hormones on the promotion and dissemination of breast cancer has been extensively discussed. When the lesion in the breast spreads beyond its territory, remission has been sought by altering the hormone environment of the body and its beneficial effect on some cases of breast cancer is well established (Luft and Olivecrona, I953; Ray and Pearson, I962). However, if metastatic deposits to the spine produce severe neurological complications such as paralysis of limbs or sphincters, the patients are often considered unsuitable for surgery (Atkins et al., 1960). Duffy (1969) reported a case of breast cancer with paraparesis treated by hypophysectomy alone. Because of severe spinal deformity laminectomy was considered impossible, but following pituitary ablation the patient showed recovery from the neurological deficit.

The purpose of this communication is to describe the experience of hypophysectomy in patients with severe neurological deficit due to spinal cord compression by metastatic deposit from breast carcinoma.

\section{CASE MATERIAL}

During the past four years, of all the patients referred to one of us (L.P.L.) with paralysis of limbs, six had metastatic deposits to the spine from breast carcinoma as the cause for their neurological deficit. Table I shows the detail of their breast lesion and its treatment.

Clinical Presentation. Table II shows the presenting symptoms with their duration. Except for one patient all had severe pain and bladder involvement before they were referred to the neurosurgical department. The pain started off as chronic backache for nearly a year or more in most cases. The duration of limb paralysis or bladder involvement was at least two days before the patients were referred. The severity of the neurological lesion was assessed by the criteria of Brice and McKissock (1965). Accordingly the neurological deficit was divided into four grades: (I) Mild-patient able to walk; (2) Moderate-able to move legs but not against gravity; (3) Severe-slight residual motor and sensory function; and (4) Complete-no motor, sensory or sphincter function below the level of the lesion.

Investigations and Preliminary Treatment. This is shown in Table III. Plain X-ray showed definite involvement of a vertebra in all cases except one. Myelogram was carried out in five of the cases and a total block to the myodil 
column was present. In three cases spinal involvement was at multiple levels. Laminectomy was carried out in three patients with lesion at a single level. In all

TABLE I

\begin{tabular}{|c|c|c|c|c|}
\hline Case & Age & $\begin{array}{l}\text { Cancer of } \\
\text { breast first } \\
\text { treated }\end{array}$ & Nature of treatment & $\begin{array}{l}\text { Onset of } \\
\text { metastatic } \\
\text { symptoms }\end{array}$ \\
\hline M. T. & 69 & I964 & Radical mastectomy & 1969 \\
\hline E. $M$. & 60 & I967 & Simple mastectomy and DXT & I970 \\
\hline I. G. & $3 I$ & I966 & $\begin{array}{l}\text { DXT_-oophorectomy bilateral } \\
\text { adrenalectomy three years later }\end{array}$ & I969 \\
\hline A. $M$. & 54 & I963 & $\begin{array}{l}\text { Simple mastectomy excision of glands } \\
\text { and oophorectomy one year later }\end{array}$ & I97I \\
\hline M. H. & 60 & - & No treatment & I 97 I \\
\hline J. E. & 43 & I 972 & Simple mastectomy & I 97 I \\
\hline
\end{tabular}

TABLE II

\begin{tabular}{|c|c|c|c|c|}
\hline Case & Pain & Motor Power & Sensory Level & $\begin{array}{c}\text { Bladder } \\
\text { Involvement }\end{array}$ \\
\hline M. T. & Io months & $\begin{array}{l}\text { Paraplegia ( } 2 \text { days) } \\
\text { Grade } 4\end{array}$ & D I I & Retention ( 2 days) \\
\hline E. $M$. & - & $\begin{array}{l}\text { Quadruplegia (2 days) } \\
\text { Grade } 3\end{array}$ & $\begin{array}{l}\text { Diffuse loss } \\
\text { of sensation }\end{array}$ & $\begin{array}{l}\text { No involvement of } \\
\text { bladder }\end{array}$ \\
\hline I. G. & I month & $\begin{array}{l}\text { Quadraparesis ( } 2 \text { days) } \\
\text { Grade } 2\end{array}$ & D 5 & Retention (I week) \\
\hline A. $M$. & 2 years & $\begin{array}{l}\text { Paraplegia ( } 2 \text { days) } \\
\text { Grade } 4\end{array}$ & D 6 & Retention (3 days) \\
\hline M. H. & I year & $\begin{array}{l}\text { Paraplegia (3 days) } \\
\text { Grade } 3\end{array}$ & D 9 & $\begin{array}{l}\text { Retention with } \\
\text { overflow ( } 2 \text { days) }\end{array}$ \\
\hline J. E. & 2 years & $\begin{array}{l}\text { Paraplegia ( } 2 \text { weeks) } \\
\text { Grade } 3\end{array}$ & D 7 & Retention (3 days) \\
\hline
\end{tabular}

patients submitted to laminectomy the lesion was found to be anterior to the cord and a small amount of tumour tissue only could be removed for biopsy. Histology in each case confirmed the metastatic nature of the tumour. 
Hypophysectomy. In three patients hypophysectomy was carried out as an emergency procedure without laminectomy as the lesions were multiple. In the remaining three, the operation was carried out two to five days after laminectomy. The pituitary gland was approached via the transfrontal intracranial route. In two patients the optic chiasma was prefixed and made the approach to the sella turcica difficult; in one of these cases the sella was found to be empty.

TABLE III

\begin{tabular}{|c|c|c|c|}
\hline Case & \multicolumn{1}{|c|}{ Plain X-ray } & Myelography & Nature of treatment \\
\hline M. T. & Collapse D.V.ro & Total block at D.V.ro & $\begin{array}{l}\text { Laminectomy and } \\
\text { biopsy }\end{array}$ \\
I. G. & $\begin{array}{l}\text { Collapse D.V.7 soft } \\
\text { tissue mass opposite } \\
\text { C.V.2 } \\
\text { Collapse C.V.2 }\end{array}$ & Total block at C.V.7 & None \\
A. M. & $\begin{array}{l}\text { Collapse C.V.2 with } \\
\text { dislocation } \\
\text { Collapse D.V.5 } \\
\text { Pulmonary mass }\end{array}$ & Not done & None \\
M. H. & $\begin{array}{l}\text { Collapse D.V.9 } \\
\text { J. E. }\end{array}$ & $\begin{array}{l}\text { N.A.D. } \\
\text { Nock at D.V.9 }\end{array}$ & $\begin{array}{c}\text { None } \\
\text { biopsy } \\
\text { block aminectomy and } \\
\text { biopsy }\end{array}$ \\
\hline
\end{tabular}

\section{RESULTS}

There was no complication following craniotomy for pituitary ablation. All patients, however, developed diabetes insipidus and this was controlled with pitressin. The result of pituitary ablation is shown in Table IV. The immediate effect was the dramatic relief of pain in three patients. The improvement in recovery of neurological function was slow but satisfactorily achieved in four patients. Only two patients failed to show improvement. To assess the effect of hypophysectomy on the tumour regression, further investigation with plain $\mathrm{X}$-ray or re-screen myelogram was performed in three of the cases. All these patients showed a regression of growth.

Result in terms of survival and its quality is shown in Table V. Of the six cases, only one patient is still alive I8 months after hypophysectomy. The first patient died one year later from myocardial infarction. The second case died I8 months later from recurrent metastases. The next two patients died within three months of pituitary ablation without showing any relief of their symptoms. The fifth patient died two years after her operation and this was due to pulmonary embolism from extensive thrombosis of the inferior ven cava. Because of the 
clear picture of metastatic regression the case record of this patient is described in detail.

TABLE IV

\begin{tabular}{|c|c|c|c|c|}
\hline Case & Pain & Motor power & $\begin{array}{l}\text { Bladder } \\
\text { function }\end{array}$ & $\begin{array}{l}\text { Post-operative } \\
\text { assessment of } \\
\text { tumour growth }\end{array}$ \\
\hline M. T. & Relief of pain & $\begin{array}{l}\text { Able to walk with } \\
\text { crutches }\end{array}$ & $\begin{array}{l}\text { Regained full } \\
\text { Control }\end{array}$ & $\begin{array}{l}\text { Regression of } \\
\text { tumour }\end{array}$ \\
\hline E. $M$. & $\ldots$ & $\begin{array}{l}\text { Able to walk } \\
\text { without help }\end{array}$ & - & $\begin{array}{l}\text { Regression of } \\
\text { tumour }\end{array}$ \\
\hline I. G. & No relief & No change & No change & $\begin{array}{l}\text { Further metastases } \\
\text { to lung and liver }\end{array}$ \\
\hline A. $M$. & No relief & No change & No change & Not done \\
\hline M. H. & Relief of pain & $\begin{array}{l}\text { Able to walk with } \\
\text { help }\end{array}$ & Improved & Not done \\
\hline J. E. & Relief of pain & $\begin{array}{l}\text { Able to walk with } \\
\text { help }\end{array}$ & Full control & $\begin{array}{l}\text { Regression of } \\
\text { growth }\end{array}$ \\
\hline
\end{tabular}

TABLE V

\begin{tabular}{|l|c|c|c|}
\hline Case & $\begin{array}{c}\text { Total duration since } \\
\text { hypophysectomy }\end{array}$ & Cause of death & Quality of survival \\
\hline M. T. & I year & Myocardial infarction & Good \\
E. M. & I8 months & Further metastases & $\begin{array}{c}\text { Good until further } \\
\text { metastases }\end{array}$ \\
I. G. & 4 months & Extensive metastases & Poor \\
A. M. & 3 months & Extensive metastases & Poor \\
M. H. & 2 years & $\begin{array}{l}\text { Pulmonary embolism. } \\
\text { Thrombosis of inferior } \\
\text { vena cava }\end{array}$ & Fair \\
J. E. & Alive (I8 months) & & Good \\
\hline
\end{tabular}

Case (M. H.). This 60-year-old lady was admitted in November I97I with a one-year history of low backache. For one week she had had progressive weakness and loss of sensation in her legs. On admission she was found to have a breast carcinoma which 
had been present at least two years. She had a flaccid paraparesis with minimal leg movement (grade 3 according to Brice \& McKissock, I965). Plain X-ray of the thoracic spine showed collapse of D.V.9. A myelogram showed complete obstruction to the upward flow of myodil at the level of the collapsed vertebra. An emergency laminectomy was carried out and a large extradural tumour was found lying mainly in front of the cord. The cord was displaced backwards by the tumour. A small amount of tumour only was removed for biopsy. No attempt was made to remove the tumour for fear of injury to the swollen and displaced cord. The histology report showed inflammatory cells with clumps of hyperchromatic cells suggestive of a carcinoma and consistant with secondary deposits from the breast. After operation there was no change in the neurological condition of the patient. Four days after laminectomy a hypophysectomy was performed by the transfrontal intracranial approach. Apart from endocrine replacement the only other therapy given was pitressin and chlorpropamide to control the diabetes insipidus. Within three months she had started to walk with some help. Fifteen months after operation she was found unconscious with a very low blood sugar level of I5 mg. per cent. Although she regained consciousness with appropriate therapy she developed oedema of the legs, breathlessness and remained bed-ridden until September I973, when she died from pulmonary embolism.

The post-mortem findings showed that the cause of death was a massive pulmonary embolism and the inferior vena cava was thrombosed. A section through the right breast revealed firm tumour tissue which had not extended to the lymph glands or bony structures. The pituitary fossa contained some remains of pituitary tissue and the pituitary stalk was intact. The region of the previous laminectomy showed no recurrence of tumour. The site of the previous extradural compression was clearly defined and it was free of macroscopic tumour.

In terms of survival the average period was 18 months in four patients who responded to therapy. The first two patients enjoyed their life after being able to be on their feet again. The quality of life in the third patient was adversely influenced by venous thrombosis although she was able to walk with some help after the operation. The patient who is still alive is enjoying her life with a large family nearly I 8 months after her operation.

\section{DISCUSSION}

It is established that some of the cases of breast cancer are hormone dependent and the pituitary is one of the most important endocrine glands involved in this process. Supression of pituitary activity by surgical or any other means is therefore an accepted form of therapy for advancing cancer of the breast with generalised metastases. However, when metastases involve the spinal column and produce severe neurological deficit, e.g. paralysis of limbs or sphincters, there is a general reluctance in advocating major surgery. In fact, Atkins et al. (1960) excluded a patient with advanced breast carcinoma from hypophysectomy because of paraplegia. Although laminectomy provides decompression of the spinal cord it does not allow effective removal of the tumour as the metastatic deposits are usually anterior to the cord. For this reason, laminectomy is often considered a fruitless surgical exercise in these cases. Moreover, if the metastases occur at multiple levels, laminectomy is not possible. Yet of all the distant metastases of breast carcinoma, those involving the spinal column with cord compression are the most unfortunate type since the patient continues to suffer from agonising pain followed by paralysis of the limbs and urinary bladder until further dissemination of a vital organ brings an end to the suffering. So any form of therapy which can improve the quality 
of life should be offered. In our experience of six cases of breast carcinoma with spinal metastases treated by hypophysectomy with or without laminectomy, it was possible to improve the quality of life and extend survival in four cases.

If the metastases are hormone dependent, hypophysectomy is known to cause regression of the secondary deposits and we have observed this regression in four patients. This was confirmed at myelography in three cases. Although the disappearance of a block in the myodil column can be ascribed to the laminectomy we have seen a similar disappearance of the block in a patient who was not submitted to laminectomy. Moreover, free flow of the myodil column anterior to the cord also suggests that the compression no longer exists. The most important evidence of total regression of metastases has been observed in one patient where postmortem facilities were available.

Hypophysectomy is thus effective even in highly advanced metastases from breast carcinoma. As the beneficial effect of hypophysectomy is confined to hormone-dependent cases only, selection of cases is of considerable practical significance. There are various studies which attempt to achieve this goal. However, to date, biochemical methods offer no conclusive way of finding this hormone dependency. Edelstyn et al. (1964, 1965) suggested some criteria for hypophysectomy in patients with breast cancer. It is interesting that most of our cases which benefited from hypophysectomy fell into the favourable group described by these authors.' We entirely agree with these criteria and feel that they should be adhered to until a conclusive biochemical method is found for pre-operative assessment of the suitability of the patients.

Another important observation was the recovery of severe neurological deficit of considerable duration. Most of the patients were operated on having had paralysis of the limbs and bladder for at least two days, yet significant improvement was observed in the majority of cases. It is possible that loss of neurological function in the initial period is due to oedema of the spinal cord and is recoverable up to a certain period. We have certainly observed this recovery of function in more than 50 per cent of these cases. Recently Hall and Mackay (1973) reported similar observations of recovery of severe neurological deficit after removal of extradural malignant tumours causing compression of the spinal cord or cauda equina. In four patients who showed recovery of function, laminectomy had been performed in three of them. Although there was no immediate improvement following laminectomy the procedure may have created sufficient room for the cord swelling.

Apart from providing a biopsy for histological diagnosis, laminectomy as a primary procedure may be useful before hypophysectomy in these cases. Besides regression of the tumour, the other beneficial effect of hypophysectomy on these patients is dramatic relief of pain. The mechanism of pain relief from endocrine ablation is not well understood. Certainly it is not related to tumour regression as relief of the pain is immediate. However, the relief of pain itself improves the quality of life. In this respect it is also interesting to note from these case studies that most of the patients suffered from intractable backache for a long time before the onset of severe neurological deficit. It is possible that earlier diagnosis may be made by appropriate investigation before the onset of severe neurological deficit.

In conclusion, when advancing breast carcinoma gives rise to severe pain and paralysis of limbs or bladder it creates an inexorable picture which can continue 
for months as survival is only indirectly threatened. Anything that can improve the quality of life is worth while and hypophysectomy in suitable cases can contribute to this.

\section{SUMMARY}

Patients who develop metastatic lesions in the spinal column from breast carcinoma do suffer a great deal of pain. When spinal cord compression causes paralysis of limbs or sphincters, the quality of life deteriorates although they may live for many months. Decompressive laminectomy alone does not significantly alter their outlook. We have found that hypophysectomy either alone or in combination with laminectomy allows regression of these tumours in some cases. We have described six patients who have been submitted to hypophysectomy and only three of these have had decompressive laminectomy. The most important result of endocrine ablation has been the relief of intractable pain. Four paralysed patients began to walk again and the improvement in the quality of their life made the surgery well worth while.

\section{RÉSUMÉ}

Les malades qui ont des lésions métastasiques au niveau de la colonne vertébrale dues à un carcinome du sein souffrent énormément. Quand la compression médullaire entraine une paralysie des membres et des sphincters, la qualité de la vie se détériore bien qu'ils puissent encore vivre pour de nombreux mois. La laminectomie décompressive seule ne change pas le pronostic. Nous avons trouvé que l'hypophysectomie, soit seule ou en combinaison avec la laminectomie, donne certaines régressions dans certains cas. Nous avons décrit les cas de six malades qui ont été soumis à l'hypophysectomie et seulement trois d'entre eux ont eu une laminectomie décompressive. Le résultat le plus important de l'hypophysectomie a été une diminution de la douleur. Quatre malades ont pu remarcher et l'amélioration de la qualité de leur vie a justifié l'acte chirurgical.

\section{ZUSAMMENFASSUNG}

Patienten mit metastatischen Läsionen der Wirbelsäule als Folge von Brustkrebs leiden an beträchtlichen Schmerzen. Wenn Rückenmarkskompression zu Paraplegie führt, verschlechtert sich die Lebensqualität. Dekrompessive Laminektomie allein genügt nicht. Wir fanden, dass Hypophysektomie entweder allein oder in Kombination mit Laminektomie erlaubt Regression dieser Tumoren in einigen Fällen. 6 Patienten hatten diese Operation, von denen nur 3 dekompressive Laminektomie hatten. Das wichtigste Resultat der endokrinen Entfernung war die Befreiung von unerträglichen Schmerzen. In 4 Patienten wurde die Gehfähigkeit widerhergestellt.

\section{REFERENCES}

Atkins, H. J. B., Falconer, M. A. Hayward, J. L., Maclean, K. S., SchurR, P. H. \& ARmitage, P. (1960). Lancet i, I I 48-I I 53.

Beatson, G. T. (I896). Lancet, ii, I04-I07.

BRICE, J. \& MCKIsSOCK, W. (I965). Brit. med. F. i, I34I.

Duffy, G. P. (1969). f. Neurosurg. 30, 615-617.

Edelstyn, G. A., Gleadhill, C. A. \& Lyons, A. R. (1964). Brit. F. Surg. 51, 32-40.

Edelstyn, G. A., Gleadhill, C. A. \& Lyons, A. R. (I965). Brit. F. Surg. 52, 953-957.

Hall, A. J. \& MackaY, N. N. S. (1973). F. Bone \& foint Surg. 55B, 3.

L.uft, R. \& Olivecrona, H. (1953). F. Neurosurg. 10, 30 I-3 I6.

Ray, B. S. \& Pearson, O. H. (I962). Surg. Clins. N. Am. 42, 419-453. 